\title{
Beasts of the Devil, Perishables, and the Natura Morta
}

\author{
Gregory Chan \\ Kwantlen Polytechnic University, Surrey, Canada
}

\begin{abstract}
Bugs have long embodied that from which we seek protection. Whether a mild irritant (a "fly in the ointment"), a costly pest to gardeners (“bug off!”), or a destructive force of Biblical proportions (a swarm of locusts), bugs are nature's warning of approaching death. This paper investigates the natura morta canvas during the Golden Age of Dutch art, focusing on how these symbols of natural evil work to enliven the visual rhetoric of the still-life as they invite spiritual contemplation. In religious-themed art, we intuitively recognize these morbid creatures as symbols of decay encroaching on domestic scenes filled with food and cut flowers. Emphasizing the short life of these perishables, bugs embody a classic tension and its dichotomous variations: the corporeal vs. the spiritual, earth vs. heaven, and sin vs. redemption. Though ostensibly a peripheral feature of the natura morta, bugs are a decidedly central motif that reflects the viewer's struggle with sin: Is it repellent, attractive, or repellently attractive? This study will concern the visual rhetoric of flies, dragonflies, and bees in the works of Osias Beert, Ambrosius Bosschaert, and Georg Flegel, with an emphasis on the beasts of the devil as icons of Dutch art.
\end{abstract}

Keywords: still-life, Dutch paintings, religious art, death

\section{Introduction}

Bugs have long embodied that from which we seek protection. Whether a mild irritant (a "fly in the ointment”), a costly pest to gardeners (“bug off!”), or a destructive force of Biblical proportions (a swarm of locusts), bugs are nature's warning of approaching death. In religious-themed art, most notably in the Flemish and Dutch still-life, we intuitively recognize these morbid creatures as symbols of decay encroaching on domestic scenes filled with food and cut flowers. Emphasizing the short life of these perishables, bugs embody a classic tension and its dichotomous variations: the corporeal vs. the spiritual, earth vs. heaven, and sin vs. redemption. The savvy viewer, and certainly the patron who commissioned such a painting, appreciate the Flemish and Dutch zeitgeist: too much sympathy for the devil can compromise a Christian's salvation. The presence of bugs teaches the viewer this lesson in spiritual awareness.

Whether interpreted as repellent, attractive, or repellently attractive, these symbols of natural evil enliven the visual rhetoric of a natura morta canvas.

\section{Bugs, Visual Rhetoric, and the Still-Life}

When bugs invade our domestic order, the reaction is swift and visceral. Given that discomfort, fear, and repulsion are typical reactions, why would a patron and his commissioned artist knowingly include bugs as a spoiler element of the composition? It simply could have been a means of showcasing the painter's skill (see the gimmicky catalogue of insects in Balthasar van der Ast's Still-Life With Flowers, Fruits and Shells, ca.

Gregory Chan, M.A., English Department, Kwantlen Polytechnic University. 
1620), or it could have involved belief in "the medieval medical adage, similia similibus curantur... painted bugs keep the real ones away" (Impelluso, 2004, p. 336). Perhaps it was a means of injecting a measure of Baroque realism into the "well-equipped, neat, and orderly clean [Dutch] kitchens with gleaming metal pots and pans scrubbed and scoured to a fare-thee-well” (Barnes \& Rose, 2002, p. 14). Whatever the case is, it was about creating a conversation piece to add to a collection. However, during the Golden Age of art in Holland, many patrons vied to own works that had greater symbolic resonance; they wanted something that simultaneously spoke to their wordly and spiritual ambitions while inviting contemplation.

\section{Case Studies: Beert and Bosschaert}

Capturing these competing ambitions are several of Osias Beert's still-life, ostensibly devoted to food. The front-and-centre presence of a dragonfly in Still-Life With Cherries and Strawberries in China Bowls (1608) draws attention despite sharing visual space with a spectacle of consumption. Exotic imports (Mediterranean olives in a pewter dish), delicate china and flatware, orchard-fresh cherries and strawberries, and a trinity of wine goblets in combination with white bread (a dual symbol of affluence and transubstantiation) compete with the dragonfly, a classic religious symbol of disease, sin, and the devil (Barnes \& Rose, 2002, p. 22; Ferguson, 1959, p. 7). On guard at the forefront of the serving table, this bug literally stands between the viewer and God, whose presence is reflected in the central goblet elevated beyond the bowls of fruit. Counterbalancing the dragonfly is a Monarch butterfly, seen in the right foreground register alighted on a serving knife. This insect symbolizes Christ's resurrection and hints at the viewers' salvation, if only they could follow the light (see the reflective surface of the knife echoed in the reflection of the glasses). Beert has re-imagined the fall: His devil is recast as dragonfly, while the apple from the Garden of Eden is represented by the red fruit. Beert purposefully fills the table-top with perishables surrounded by bugs to emphasize our invulnerability to death. Still-Life With Cherries and Strawberries in China Bowls, then, warns us that immediate pleasures are temptations that can distract us from what lies just beyond: the lasting peace of God's salvation. It is within reach, but it must be given our full and mindful attention. Perhaps the painting's lesson lies between damnation and salvation in moderation, as "Alteveel is ongesont (too much is unhealthy)" (Barnes \& Rose, 2002, p. 32).

Ambrosius Bosschaert's Vase of Flowers (1620) provided a more overt commentary on the spiritual destructiveness of transient pleasures. On the periphery of a bouquet in mid-wilt, he rendered a caterpillar and dragonfly with realism and "great delicacy" (Fuchs, 1978, p. 109). The caterpillar-to-butterfly metamorphosis is symbolic of Christ's resurrection and, by extension, our spiritual transformation (Ferguson, 1959, p. 7). The caterpillar-dragonfly pairing suggests a classic good vs. evil entanglement (Impelluso, 2004, p. 336). Which force of nature will prevail? If the caterpillar is too subtle, the stilted-arch window that frames Bosschaert's floral arrangement offers an architectural reminder of God's presence. The vase of flowers perched in the church-like window frame captures the beauty of nature while it documents death in progress. Far from passive symbols, the insects in this still-life have already perforated several leaves; viewers feel the heaviness of the drooping blooms towards the base of the arrangement. Death is imminent. Through its placement and interplay of bugs, Bosschaert's piece instructs the viewer to seek out spiritual salvation before it is too late. His floral piece is less subtextual than Beert's, though equally determined in its need to be more than a showpiece.

Another work by Bosschaert, Still-Life of Flowers (1614), echoes this tension between God and the devil through its use of bugs. This floral portrait pits worthy and familiar adversaries against each other: the dragonfly vs. a duo of butterflies. Added to the mixture is a third insect, aligned in virtue with the two 
butterflies - the bee. Once again, the demonic dragonfly appears prominently in the foreground of the composition, only by this time it shares the spotlight with a regal butterfly. Demonstrating her industriousness, a bee alights on a White Dawn rose in the centre of the basket of cut flowers; joining her in the floral arrangement is a Monarch butterfly atop a pink rose occupying the right mid-register. Bees are symbolic of the Virgin Mary, as their production of honey concerns sacrifice and hard work (Ferguson, 1959, p. 7). The centrality of Bosschaert's bee and the prominence of his butterflies overwhelm the dragonfly. God's presence is the prevailing force. Even if the dragonfly and the butterfly were removed from the canvas, the bee would still be the central insect of the composition.

\section{Baroque Variations: Pious Symbolism and Chiaroscuro}

In the style of still-life painters like Beert and Bosschaert, Baroque artist Georg Flegel and his Still-Life With Fish (1637) highlighted the "parallels between the developments that were taking place in the Netherlands and Frankfurt at the time” (Meijer, 1990-1991, p. 92) and provided a hybrid German/Dutch variation on the continuing theme of spiritual awareness. His piece elevates the visual rhetoric to a sermon, with religious symbolism occupying all corners of the canvas. Here, the subtle motif of spiritual protection has been replaced by an overt message of pious edification. This becomes apparent with the plate placed before the viewer in the painting's foreground, which offers a traditional symbol of Jesus Christ: fish. In combination with the loaf of bread just behind it, the plate of fish represents both the Eucharist and the Last Supper. As the "food of the faithful", fish and bread remind Christians of Christ's sacrifice: "In various representations of the Last Supper in early Christian art, bread and fish are depicted on the table, where fish takes the place of wine as one of the two elements in the Eucharist” (Hooke, 1961, p. 537). Eucharistic symbols, the fish and the bread also allude to the feeding of the 5,000 miracle from the Gospel of John, who is referenced (as the Fourth Gospel) by the four sprigs of parsley on Flegel's plate (John 6: 1-14). The transformative power of the Son of God is further portrayed by the pitcher of wine (or Christ's blood), the third symbol of the Eucharist and the Last Supper. Flegel's color balancing captures a window's reflection along the pitcher's rim, neck, and base; these three windows, symbolic of the Holy Trinity, resemble the arched, Gothic windows of a cathedral. Taken together, these three reflections comprised of three windows add up to the perfect Christian number: nine. An angelic number, nine is symbolic of completeness, finality, or judgment (Ferguson, 1959, p. 92; “Meaning of Numbers”). Introspective viewers are reminded of their final judgment through the symbolism of food and drink.

Much like the Flemish and Dutch still-life artists, Flegel incorporated religious symbolism, chiaroscuro (dark plate and background vs. the bread and reflective pitcher), and realism into his canvases. Still-Life With Fish introduces a spoiler to the Eucharistic scene in the form of two demonic flies. The one in the upper-right register has a three-dimensional quality to it; its jarring realism, a tromp l'oeil, has shock value, drawing the viewer's eye away from the plate of fish. Here, once again, is the depiction of Christ (the fish) vs. the Devil (the fly). While chiaroscuro dramatically highlights the presence of the fully-articulated fly on the loaf of bread, it allows the second fly to remain hidden on the darkened periphery of the plate (though the color balancing of its wings almost gives it away). If the viewer accepts Flegel's painting as an allusion to the Eucharist, then the flies are a reminder that the devil is present wherever God is. Going a step further, if the fish-bread-wine combination suggests the Last Supper, then the presence of the fly on the bread and on the plate could be interpreted as the Devil and Judas, respectively. Note how the Devil Fly makes his presence known, whereas 
the Judas Fly is hiding himself amongst the fish. According to this layer of interpretation, the viewer is not only made a participant in the transubstantiation, but also bears witness to Judas's betrayal of Christ. Overall, the fly is a powerful symbol of the dark side of faith.

\section{Conclusions}

Bugs, whether they are flies, dragonflies, bees, or butterflies, signify death in the pious still-life. Their intimate relationship with nature's bounty—represented by flowers and fruit—is meant to disconcert the viewer and inspire introspection, as seen in the works of Beert, Bosschaert, and Flegel. Though bugs would lose their symbolism in the secular still-life (see Maria Sibylla Merian's Metamorphosis Insectorum Surinamensium, 1705), their status as beasts of the devil remains iconic.

\section{References}

Barnes, D. R., \& Rose, P. G. (2002). Matters of taste: Food and drink in seventeenth-century Dutch art and life. Syracuse, New York: Syracuse University Press.

BergstrÖm, I. (1956). Dutch still-life painting in the seventeenth century. (C. HedstrÖm \& G. Taylor, Trans.). London: Faber and Faber.

Ferguson, G. (1959). Signs and symbols in Christian art. New York: Oxford University Press.

Fuchs, R. H. (1978). Dutch painting. London: Thames and Hudson.

Grootenboer, H. (2005). The rhetoric of perspective: Realism and Ilusionism in seventeenth-century Dutch still-life painting. Chicago: The University of Chicago Press.

Hooke, S. H. (1961). Fish Symbolism. Folklore, 72(3), 535-538.

Impelluso, L. (2004). Nature and its symbols. (S. Sartarelli Trans.). Los Angeles: Getty Publications.

Meijer, F. G. (1990-1991). Untitled review. Simiolus: Netherlands Quarterly for the History of Art, 20(1), 91-98.

Rose, P. G. (2002). Matters of taste. Syracuse, New York: Syracuse University Press.

The Bible Study Site. (2010, May 6). Meaning of numbers in the Bible. Retrieved from http://www.biblestudy.org/bibleref/meaning-of-numbers-in-bible/9.html 